Research Article

\title{
Pengaruh Ekstrak Tumbuhan Melastoma malabathricum sebagai Larvasida Nabati terhadap Mortalitas Aedes aegypti L
}

\author{
The Effect of Melastoma malabathricum Extract as Natural Larvicide on Mortality of \\ Aedes aegypti $L$ \\ Raudatul Mahfud ${ }^{1}$, Bejo Basuki ${ }^{1}$, Shanty Savitri ${ }^{1^{*}}$ \\ ${ }^{1}$ Program Studi Pendidikan Biologi, Fakultas Keguruan dan IImu Pendidikan, Universitas Palangka Raya, \\ Palangka Raya, Indonesia \\ *email: shantysavitri@gmail.com
}

Kata Kunci:

Melastoma malabathricum

Aedes aegypti L.

Larvasida

Mortalitas

$D B D$

Key Words:

Melastoma malabathricum

Aedes aegypti L.

Larvacida

Mortality

Dengue Fever

Submitted: 06/06/2021

Revised: 08/06/2021

Accepted: 10/06/2021
Abstrak. Tingginya kasus DBD di Indonesia erat kaitannya dengan peningkatan mobilitas penduduk sejalan dengan tersebarnya nyamuk Aedes aegypti $L$ sebagai vektor yang membawa virus dengue di berbagai wilayah di Indonesia. Sehingga, perlu adanya upaya pencegahan yang bisa dilakukan seperti pembuatan larvasida nabati untuk mengurangi penyebaran atau jumlah larva nyamuk di lingkungan masyarakat. Sejalan dengan hal itu, pengembangan potensi tumbuhan lokal juga harus dilakukan. Penelitian ini bertujuan untuk mengetahui pengaruh aktivitas ekstrak tumbuhan karamunting (Melastoma malabathricum) dalam membunuh larva nyamuk Aedes aegypti L. Penelitian ini merupakan penelitian eksperimental dengan Rancangan Acak Lengkap (RAL) yang terdiri dari perlakuan P0 (kontrol negatif), P1 (kontrol positif), P2 (ekstrak batang karamunting), P3 (ekstrak daun karamunting), dan P4 (ekstrak akar karamunting) pada konsentrasi $3.5 \%$ serta terdapat 5 ulangan pada masing-masing perlakuan dengan jumlah sampel 500 larva Aedes aegypti L. Pembuatan ekstraksi simplisia batang, daun, dan akar karamunting menggunakan metode maserasi dan pelarut ethanol $70 \%$. Hasil penelitian menunjukkan pemberian ekstrak simplisia batang, daun, dan akar tumbuhan karamunting (Melastoma malabathricum) dengan konsentrasi $3.5 \%$ pada media air tempat hidup larva mampu menyebabkan kematian yang signifikan seiring lamanya waktu pengamatan. Berdasarkan uji lanjut, diketahui bahwa perlakuan P2 yaitu pemberian ekstrak batang karamunting merupakan perlakuan terbaik dalam menyebabkan kematian larva Aedes aegypti L.

Abstract. The high number of dengue cases in Indonesia is closely related to the increase in population mobility in line with the spread of the Aedes aegypti $L$ mosquito as the vector that carries the dengue virus in various regions in Indonesia. Thus, it is necessary to take preventive measures that can be done such as the manufacture of vegetable larvicides to reduce the spread or number of mosquito larvae in the community. In line with this, the development of local plant potential must also be carried out. This study aims to determine the effect of the activity of karamunting plant extract (Melastoma malabathricum) in killing Aedes 
aegypti $L$ mosquito larvae. This study was an experimental study with Completely Randomized Design (CRD) consisting of 5 treatments, namely P0 (negative control), P1 (positive control), P2 (karamunting stem extract), $P 3$ (karamunting leaf extract), and $P 4$ (karamunting root extract) at a concentration of $3.5 \%$ and there were 5 replications in each treatment with a sample of 500 Aedes aegypti $L$ larvae. Making simplicia extraction of stems, leaves, and karamunting roots using maceration method and $70 \%$ ethanol solvent. The results showed that the simplicia extract of stems, leaves, and roots of the Karamunting plant (Melastoma malabathricum) with a concentration of $3.5 \%$ in the water medium where the larvae lived was able to cause significant death over the length of time observed. Based on further tests, it was found that the P2 treatment, namely the administration of karamunting stem extract, was the best treatment in causing the death of Aedes aegypti $L$ larvae.

This is an open access article distributed under the Creative Commons 4.0 Attribution License, which permits unrestricted use, distribution, and reproduction in any medium, provided the original work is properly cited. @2021 by author.

\section{PENDAHULUAN}

Demam Berdarah Dengue (DBD) merupakan masalah kesehatan masyarakat di Indonesia. Penyakit DBD adalah penyakit yang disebabkan oleh virus dengue yang ditularkan melalui gigitan nyamuk dari genus Aedes, terutama species Aedes aegypti L. Menurut Dinas Kesehatan Republik Indonesia, jumlah penduduk yang mengalami penyakit demam berdarah meningkat sejak tahun 2014. Diambil dari data Profil Kesehatan Indonesia, jumlah penderita DBD yang dilaporkan sebanyak 68.407 kasus dan jumlah kematian 493 orang pada tahun 2017. Jika dibandingkan dengan tahun 2016 mengalami penurunan yang signifikan sebanyak 204.171 kasus penderita serta jumlah kematian sebanyak 1.105 orang. Keadaan tersebut erat kaitannya dengan peningkatan mobilitas penduduk sejalan dengan tersebarnya nyamuk penular atau vektor yang membawa virus dengue di berbagai wilayah di Indonesia (Kemenkes RI, 2018).

Nyamuk Aedes aegypti L saat ini masih menjadi vektor penyakit demam berdarah yang utama. Vektor dari penyakit DBD adalah nyamuk Aedes aegypti L betina. Nyamuk ini memiliki ciri khusus ditandai dengan pita atau garis-garis putih keperakan di atas dasar hitam, ukuran nyamuk Aedes aegypti L berkisar sekitar 3$4 \mathrm{~mm}$ dengan ring putih pada bagian kakinya (Soegijanto, 2006).

Larvasida nabati diartikan sebagai pestisida yang bahan dasarnya berasal dari tumbuhan. Larvasida nabati relatif mudah dibuat dengan kemampuan dan pengetahuan yang terbatas. Oleh karena terbuat dari bahan alami, maka jenis insektisida ini residunya mudah hilang akibat degradasi atau penguraian yang cepat oleh sinar matahari, udara, kelembaban, dan komponen alam lainnya, sehingga mengurangi risiko pencemaran tanah dan air. Selain itu, umumnya larvasida alami memiliki toksisitas yang rendah pada mamalia karena sifat inilah yang menyebabkan larvasida alami memungkinkan untuk diterapkan pada kehidupan sehari-hari (Pratiwi, 2012).

Pemilihan larvasida nabati dengan menggunakan ekstraksi tumbuhan karamunting (Melastoma malabathricum) 
merupakan kegiatan uji coba dan bertujuan mengetahui pengaruh kandungan senyawa aktif seperti saponin, flavinoid, dan tanin terhadap mortalitas larva nyamuk Aedes aegypti L, sehingga dapat meningkatkan potensi tumbuhan karamunting di pulau Kalimantan, khususnya di Kalimantan Tengah. Penerapan pada tahap larva juga menjadikan alasan untuk membasmi sedini mungkin pada perkembangbiakan nyamuk Aedes aegypti L yang biasanya ditemukan pada genangan air, maupun aktivitas rumah tangga. Adanya upaya penelitian ini juga dapat menjadi salah satu sarana penyediaan informasi tambahan di dunia tumbuhan pada bidang pendidikan serta mengurangi perkembangbiakan nyamuk Aedes aegypti L.

\section{BAHAN DAN METODE}

\subsection{Bahan dan Alat}

Bahan yang digunakan dalam penelitian ini adalah batang, daun, dan akar karamunting, larutan ethanol $70 \%$, abate serta air sumur (air tanah) dengan $\mathrm{pH}$ 6.6-7.

Alat yang digunakan pada penelitian ini adalah gelas kimia, pinset, toples plastik, baskom, batang pengaduk, saringan (kain kasa), pipet tetes, neraca digital, termometer, blender, $\mathrm{pH}$ meter, rotary evaporator, kamera digital, stopwatch.

\subsection{Metode}

Metode penelitian yang digunakan dalam penelitian ini adalah penelitian eksperimen dengan Rancangan Acak Lengkap (RAL) dan menggunakan teknik analisis data One-Way ANOVA serta uji lanjut berupa BNT. Perlakuan yang digunakan dalam penelitian ini, dapat dilihat seperti pada Tabel 1.
Tabel 1. Perlakuan Penelitian

\begin{tabular}{|c|c|c|c|}
\hline No. & Perlakuan & Kode & Keterangan \\
\hline \multirow{4}{*}{1} & & \multirow{4}{*}{ P0 } & Tanpa \\
\hline & Kontrol & & Pemberian \\
\hline & Negatif & & Ekstrak \\
\hline & & & Karamunting \\
\hline \multirow{2}{*}{2} & Kontrol & \multirow{2}{*}{ P1 } & Bubuk \\
\hline & Positif & & Abate \\
\hline \multirow{3}{*}{3} & \multirow{3}{*}{ Perlakuan 1} & \multirow{3}{*}{ P2 } & Ekstrak \\
\hline & & & Batang \\
\hline & & & Karamunting \\
\hline \multirow{3}{*}{4} & \multirow{3}{*}{ Perlakuan 2} & \multirow{3}{*}{ P3 } & Ekstrak \\
\hline & & & Daun \\
\hline & & & Karamunting \\
\hline 5 & Perlakuan 3 & P4 & $\begin{array}{l}\text { Ekstrak Akar } \\
\text { Karamunting }\end{array}$ \\
\hline
\end{tabular}

Parameter yang diukur yaitu jumlah mortalitas larva Aedes aegypti L setelah diberikan perlakuan. Penentuan konsentrasi yang digunakan dalam penelitian ini mengacu pada penelitian yang dilakukan oleh Winda (2010) yaitu $3.5 \%$ setiap perlakuan. Sampel Penelitian yang digunakan yaitu 500 ekor dengan pemberian 20 ekor pada setiap perlakuan terhadap ulangannya. Proses pembuatan larvasida dari bahan tumbuhan karamunting menggunakan metode maserasi, simplisia batang, daun dan akar karamunting dipisahkan, dikeringkan serta ditimbang seberat 100 g. Kemudian ditempatkan pada masing-masing toples kaca lalu diberikan pelarut ethanol $70 \%$ sebanyak $700 \mathrm{ml}$ selama $2 \times 24$ jam pada tahap maserasi. Hasil rendaman pada tahap maserasi disaring dan kemudian masuk ke tahap remaserasi dengan memberikan pelarut ethanol $70 \%$ pada sisa simplisia tahap pertama sebanyak $300 \mathrm{ml}$ selama 1x24 jam. Hasil ekstraksi dilakukan pemekatan menggunakan alat rotary evaporator 
dengan suhu $60^{\circ} \mathrm{C}$ yang bertujuan menghilangkan sisa zat pelarut ethanol.

\section{HASIL DAN PEMBAHASAN}

Berdasarkan hasil pengamatan selama 48 jam, aktivitas dari pemberian larvasida ekstrak tumbuhan karamunting bagian batang, daun dan akar terhadap mortalitas larva Aedes aegypti L disajikan dalam bentuk grafik dan tabel.

Grafik pada Gambar 1 menunjukkan pengamatan yang dilakukan setiap 6 jam sekali. Pada 6 jam pertama perlakuan P0 (Kontrol negatif) tidak menunjukkan adanya kematian larva dan perlakuan P1 (Kontrol positif) menunjukkan kematian larva tertinggi. Perlakuan P2, P3, P4 menunjukan adanya pengaruh terhadap kematian larva dengan besar rata-rata dibawah $\mathrm{P} 1$. Pengamatan 12 jam dengan perlakuan $\mathrm{P} 2$, P3 dan P4 mengalami peningkatan, dengan P2 mendekati rata-rata kematian P1. Pada pengamatan 18 jam hingga 48 jam perlakuan P3 dan P4 mengalami peningkatan rata-rata terhadap kematian larva Aedes aegypti L. Hal ini menunjukkan bahwa aktivitas pemberian ekstrak karamunting terhadap kematian larva meningkat seiring lamanya waktu.

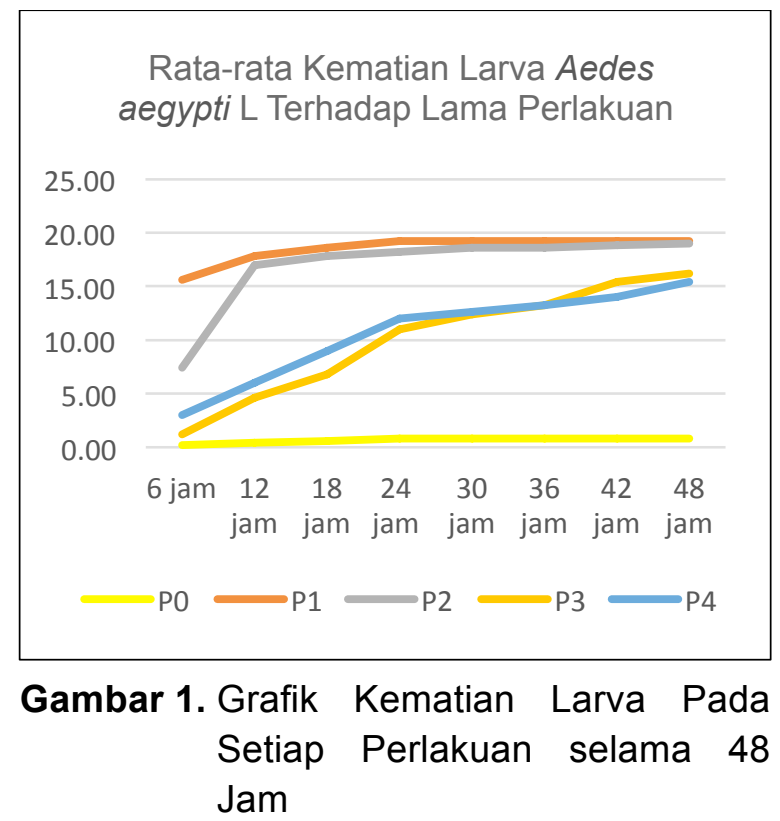

Tabel 2. Data Hasil Pengamatan Aktivitas Ekstrak Tumbuhan Karamunting terhadap Mortalitas Larva Aedes aegypti L

\begin{tabular}{cccccccc}
\hline \multirow{2}{*}{ Perlakuan } & \multicolumn{5}{c}{ Ulangan } & Jumlah & Rata-rata \\
\cline { 2 - 5 } & I & II & III & IV & V & & \\
\hline P0 & 1 & 0 & 2 & 1 & 0 & 4 & 0.8 \\
P1 & 20 & 19 & 19 & 19 & 19 & 96 & 19.2 \\
P2 & 19 & 18 & 20 & 18 & 20 & 95 & 19 \\
P3 & 16 & 15 & 17 & 18 & 15 & 81 & 16 \\
P4 & 14 & 15 & 17 & 14 & 17 & 77 & 15 \\
\hline Jumlah & 70 & 67 & 75 & 70 & 71 & $\mathbf{3 5 3}$ & 14.1 \\
\hline
\end{tabular}

Tabel 3. Hasil Analisis Uji Hipotesis: One-Way ANOVA

\begin{tabular}{lrrrrr}
\hline Sumber Keragaman & db & JK & KT & F hit. & F.Tabel 5\% \\
\hline Perlakuan & 4 & 1165.04 & 291.26 & 246.83 & 2.67 \\
Galat Percob. & 20 & 23.60 & 1.18 & & \\
\hline Total & 24 & 1188.64 & & & \\
\hline
\end{tabular}


Berdasarkan Tabel 2, dapat diketahui bahwa terdapat perbedaan jumlah rerata hasil pengamatan aktivitas perlakuan kontrol dan ekstrak tumbuhan karamunting terhadap mortalitas larva Aedes aegypti L pada masing-masing kelompok perlakuan. Rerata hasil pengamatan pada perlakuan P2 (ekstrak batang karamunting) mendekati rerata hasil perlakuan P1 (kontrol positif), sehingga $\mathrm{P} 2$ dan $\mathrm{P} 1$ tidak berbeda nyata. Rerata P3 (ekstrak daun karamunting) lebih besar dibandingkan P4 (ekstrak akar karamunting), dimana perlakuan P4 memiliki jumlah dan rerata kematian larva Aedes aegypti L terkecil setelah P0 (kontrol negatif). Urutan jumlah dan rerata mortalitas larva dari yang terbesar hingga yang terkecil yaitu P1, P2, P3, P4 dan P0. Hal ini menunjukkan adanya perbedaan yang signifikan dari aktivitas ekstrak tumbuhan karamunting terhadap mortalitas larva Aedes aegypti L.

Data yang telah diperoleh kemudian dilakukan analisis menggunakan One-Way ANOVA yang secara rinci disajikan pada Tabel 3. Dengan ketelitian 95\% (0.05) pada Tabel 3 menunjukkan nilai $F_{\text {hitung }}(246.83)>$ $F_{\text {tabel }}$ \% (2.67) sehingga dapat dinyatakan ada perbedaan yang signifikan pada hasil pengamatan pengaruh ekstrak batang, daun dan akar tumbuhan karamunting terhadap mortalitas larva Aedes aegypti $\mathrm{L}$ dengan pembanding yaitu kontrol negatif tanpa diberikan perlakuan khusus serta kontrol positif yaitu pemberian abate.

Senyawa yang berperan penting pada tumbuhan karamunting sebagai larvasida nabati yaitu saponin, flavonoid dan tanin. Proses mortalitas larva terjadi akibat aktivitas senyawa terhadap metabolisme larva. Hal ini sesuai dengan teori yang dikemukakan oleh Haditomo, (2010) bahwa efek larvasida senyawa saponin, flavonoid dan tanin yaitu sebagai stomach poisoning atau racun perut. Senyawa-senyawa tersebut larut di dalam air dan akhirnya masuk sistem pencernaan serta mengakibatkan gangguan sistem pencernaan larva, sehingga larva gagal tumbuh dan akhirnya mati. Namun, belum adanya penelitian lebih lanjut terhadap pengaruh perubahan kualitas media air berupa warna dan aroma pada pemberian ekstraksi batang, daun dan akar karamunting dalam menyebabkan kematian pada larva, hanya saja perubahan warna dan aroma media air larva disebabkan oleh perbedaan struktur jaringan dari masingmasing bahan ekstraksi.

\section{KESIMPULAN}

Aktivitas ekstrak tumbuhan karamunting bagian batang, daun dan akar pada konsentrsi $3.5 \%$ memiliki potensi dalam menyebabkan mortalitas larva Aedes aegypti $L$ seiring lamanya waktu pengamatan dan hasil uji lanjut BNT menunjukkan ekstrak batang karamunting merupakan perlakuan terbaik dalam menyebabkan kematian larva.

\section{Daftar Pustaka}

Agustin, I. 2017. Perilaku bertelur dan siklus hidup Aedes aegypti pada berbagai media air. Jurnal Biologi, Volume 6 No 4, Oktober 2017. Hal. 71-8. Laboratorium Ekologi dan Biosistematik Departemen Biologi FSM UNDIP.

Balai Penelitian Tanaman Obat dan Aromatik. 2006. Mengatasi Demam Berdarah dengan Tanaman Obat. Warta Penelitian dan Pengembangan Pertanian Vol 28 No. 6. Bogor. p: 6 
Borror DJ. Triplehorn C.A \& Johnson NF. 1996. Pengenalan Pelajaran Serangga Edisi Keenam. Partosoedjono S, penerjemah; Brotowidjoyo MD, editor. Yogyakarta: Gadjah Mada University Press. Terjemahan dari: An Introduction to The Study of Insects.

Calvacanti E.S.B, de Morais S.M, Lima A.M.A and Santana E.W.P. 2004. Larvicidal Activity of Essential Oils from Brazilian Planta againts Aedes aegypti L. Mem Inst Oswaldo Cruz 99(5): 541-544

Chotimah, S. Kresnatita, Y.Miranda. 2013. Ethnobotanical study andnutrient content of indigenous vegetables consumed in Central Kalimantan. J. Biodiversitas 14

Depkes RI. 2005. Pencegahan Dan Penanggulangan Penyakit Demam Dengue Dan Berdarah Dengue. Ditjen PPM \& PLP. Jakarta

Fitria dan A. Lenny. 2009. Uji Aktivitas Antikanker In Vitro dengan Sel Murine P-388 Senyawa Flavonoid dari Fraksi Etilasetat Akar Tumbuhan Tunjuk Langit (Helminthostachys zeylanicaL. Hook)

Haditomo, Indriantoro (2010) Efek Larvasida Ekstrak Daun Cengkeh (Syzygium aromaticum L.) Terhadap Aedes aegypti L. (Skripsi). Surakarta : Universitas Sebelas Maret.

Jalil, J., A.A. Bdin, dan T.S Chye, 1986. Phyotochemical Study Of Ophioglosaceae Family Species, Proc Malays Bio Chemistry Sociaty

Jirakanjanakit N. and J.P Dujardin. 2005. Discrimination of Aedes aegypti (Diptera: Culicidae) Laboratory Lines Based on Wing Geometry. The Southeast Asian Journal of Tropical
Medicine and Public Health. 36 (4): 858-861.

Kardinan, A. 2003. Tanaman Pengusir dan Pembasmi Nyamuk. Jakarta: Agro Media Pustaka. Pp: 2-5, 22-23, 28-29

Nath, Deepa. D. Manabendra 2014. Phytochemical profiling of Melastoma malabathricum. L (Melastomataceae): An Ethomedically Important Plant Of Eastern Himalaya. Assam University, Silchar : India

Pratiwi, A. 2012. Penerimaan Masyarakat terhadap Larvasida Alami, Jurnal Kesehatan Masyarakat.

Romdonawati, Y. 2008. Ekstrak Daun Kirinyu (Chromolaena odorata L. R. $M$. King and H. E. Binso) Sebagai Larvasida nyamuk Aedes aegypti. FMIPA Universitas Sebelas Maret, Skripsi.

Sarker B, F.Akther, U.Ayman, R.Sifa , I.Jahan , M.Sarker, S.K.Chakma, PK.Podder, Z. Khatun , M. Rahmatullah. 2012. Ethnomedicinal investigations among the Sigibe clan of the Khumi tribe of Thanchi subdistrict in Bandarban district of Bangladeesh. Amer-Eur J Sustain Agric 6 (4): 378386

Segijanto, S. 2006. Epidemiologi Demam Berdarah Dengue. Surabaya: Airlangga University Press

Suharyanto. 2019. Potensi Ekstrak Daun (Melastoma malabathricum L sebagai Food Additive pada sosis daging sapi. Fakultas Kedokteran Hewan, Institut Pertanian Bogor, Bogor

Sukesi, T. 2012. Monitoring populasi nyamuk Aedes aegypti vektor penyakit demam berdarah di Kelurahan Gedongkiwo Kecamatan Mantrijeron Kota Yogyakarta. Fakultas 
Kesehatan Masyarakat Universitas Ahmad Dahlan Yogyakarta.

Widhiarso, W. 2011. Aplikasi anava campuran untuk desain eksperimen pre-post test design. Yogyakarta: Fakultas Psikologi UGM.

Winda, R. Anggriani, Dyah. (2010) Uji Larvasida Ekstrak Rimpang Lengkuas (Alpinia galanga SW) Terhadap Kematian Larva Nyamuk Aedes aegypti. Universitas Muhammadiah, Surakarta 